\title{
Holocene Sedimentary Environment in HP1 Core at Duong Kinh, Haiphong
}

\author{
Nguyen Thi Thu Cuc ${ }^{1, *}$, Nguyen Thuy Duong ${ }^{1}$, Nguyen Thi Minh Phuong ${ }^{2}$, \\ Doan Dinh Lam ${ }^{3}$, Vu Van Loi ${ }^{4}$, An Thi Thuy ${ }^{5}$, Nguyen Thi Xuan ${ }^{6}$ \\ ${ }^{1}$ VNU University of Science, Vietnam National University, Hanoi, 334 Nguyen Trai, Hanoi, Vietnam \\ 2 Duy Tan University, 254 Nguyen Van Linh, Da Nang,Vietnam
}

${ }^{3}$ Institute of Geological Sciences, Vietnam Academy of Science and Technology, 84 Chua Lang, Hanoi, Vietnam

${ }^{4}$ Hai Phong Construction Design and Consultant Joint stock company, 36 Ly Tu Trong, Hong Bang, Hai Phong, Vietnam

${ }^{5}$ Vietnam National Museum of Nature, Vietnam Academy of Science and Technology, 18 Hoang Quoc Viet, Ha Noi, Vietnam

${ }^{6}$ Vietnam Association for Paleontology and Stratigraphy, 334 Nguyen Trai, Hanoi, Vietnam

\begin{abstract}
Holocene environment change in Haiphong coastal area was reconstructed based on diatom and grain-size analysis in the HP1 core at Duong Kinh, Haiphong. 52 diatom species were identified and divided in five diatom ecozones by changing of four diatom groups including marine planktonic, brackish planktonic, brackish benthic and freshwater one. The sedimentary environment at the Haiphong coastal area was estuary- bay condition in the Flandrian trangression $\left(Z_{1}, Z_{2}\right.$ and $Z_{3}$ Unit). Deltaic environment changed from prodelta $\left(Z_{4}\right)$, delta front $\left(Z_{5}\right)$ to delta plain $\left(Z_{6}\right.$ and $\left.Z_{7}\right)$ corresponding to the Flandrian regression.
\end{abstract}

Keywords: Haiphong coastal area, diatom, grain-size, Flandrian trangression, Holocene.

\footnotetext{
* Corresponding author.

E-mail address: thucuc.kdc@gmail.com

https://doi.org/10.25073/2588-1094/vnuees.4326
} 


\title{
Môi trường trầm tích Holocen tại lỗ khoan HP1 Dương Kinh, Hải Phòng
}

\author{
Nguyễn Thị Thu Cúc ${ }^{1, *}$, Nguyễn Thùy Dương ${ }^{1}$, Nguyễn Thị Minh Phương ${ }^{2}$, \\ Doãn Đình Lâm ${ }^{3}$, Vũ Văn Lợi ${ }^{4}$, An Thị Thùy ${ }^{5}$, Nguyễn Thị Xuân ${ }^{6}$ \\ ${ }^{1}$ Truoòng Đại học Khoa học Tụ̣ nhiên, Đại học Quốc gia Hà Nội, 334 Nguyễn Trãi, Hà Nội, Việt Nam \\ ${ }^{2}$ Đại học Duy Tân, 254 Nguyễn Văn Linh, Đà Nã̃ng, Việt Nam \\ ${ }^{3}$ Viện Địa chất-Viện Hàn lâm Khoa học và Công nghệ Việt Nam, 84 Chùa Láng, Hà Nội, Việt Nam \\ ${ }^{4}$ Công ty cổ phần tur vấn thiết kế công trình xây dụng Hải Phòng, \\ 36 Lý Tụ Trọng, Hồng Bàng, Hải Phòng, Việt Nam \\ ${ }^{5}$ Bảo tàng Thiên nhiên Việt Nam, 18 Hoàng Quốc Việt, Hà Nội, Việt Nam \\ ${ }^{6} H$ ọi Cổ sinh-Địa tầng Việt Nam, 334 Nguyễn Trãi, Hà Nội, Việt Nam \\ Nhận ngày 26 tháng 11 năm 2018 \\ Chỉnh sửa ngày 31 tháng 12 năm 2019; Chấp nhận đăng ngày 15 tháng 01 năm 2020
}

\begin{abstract}
Tóm tắt: Bài báo bước đầu khôi phục sự thay đổi môi trường thành tạo trầm tích Holocen vùng ven biển Hải Phòng dựa trên kết quả phân tích tảo Diatomeae và độ hạt tại lỗ khoan HP1-Quận Dương Kinh, thành phố Hải Phòng. 52 loài diatom được nhận biết và phân chia thành năm đới sinh thái Diatomeae dựa trên sự thay đổi tỷ lệ của 4 nhóm sinh thái đặc trưng cho 4 kiểu môi trường khác nhau bao gồm nhóm biển trôi nổi, nhóm nước lợ trôi nổi, nhóm nước lợ bám đáy và nhóm nước ngọt. Trên cơ sở đặc điểm trầm tích kết hợp với sự phân bố của các đới sinh thái Diatomea, bốn kiểu môi trường trầm tích được xác lập cho vùng ven biển Hải Phòng tại lỗ khoan HP1: estuary-vũng vịnh, ứng với giai đoạn biển tiến Flandrian (thành tạo tập trầm tích $Z_{1}, Z_{2}$ và $Z_{3}$ ), chân châu thổ (tập $\mathrm{Z}_{4}$ ), tiền châu thổ (tập $\mathrm{Z}_{5}$ ) và đồng bằng châu thổ (tập $\mathrm{Z}_{6}$ và $\mathrm{Z}_{7}$ ) ứng với giai đoạn biển lùi trong Holocen.
\end{abstract}

Tù khóa:ven biển Hải phòng, Diatomeae, độ hạt, biển tiến Flandrian, Holocen.

\section{Mở đầu}

Vùng ven biển (coastal areas) là nơi giao thoa giữa môi trường lục địa và môi trường biển, nơi tranh chấp giữa đất liền và biển. Chính vì thế vùng ven biển lưu giữ được những dấu ấn của các đợt biển tiến, biển thoái đã diễn ra cùng với sự hình thành và phát triển của nó. Dấu ấn của quá trình biển tiến, biển thoái có thể tìm thấy trong trầm tích trên cơ sở nghiên cứu đặc điểm thành phần thạch học [1-4], cổ sinh [5-8] và đã được các nhà nghiên cứu địa chất trên thế giới sử dụng nhằm khôi phục điều kiện cổ môi trường, cổ địa lý liên quan đến các pha biển tiến và biển thoái [9-15].

Vùng ven biển Hải Phòng là vùng tiếp giáp với biển Đông, nằm ở phía bắc và là một phần

\footnotetext{
* Tác giả liên hệ.

Địa chỉ email: thucuc.kdc@ gmail.com

https://doi.org/10.25073/2588-1094/vnuees.4326
} 
của châu thổ Sông Hồng. Đây là vùng kinh tế trọng điểm của đất nước có lịch sử phát triển địa chất đa dạng, tài nguyên cảnh quan phong phú nên việc nghiên cứu địa chất ở vùng này được các nhà địa chất trong và ngoài nước quan tâm, nghiên cứu. Theo các nghiên cứu đã công bố thì vùng này chịu sự thống trị của triều là chính $[3,9,16]$. Các công trình nghiên cứu trước đây về sự hình thành đồng bằng và dao động mực nước biển trong Holocen đã phản ánh được lịch sử phát triển của châu thổ Sông Hồng, nhưng vùng ven biển Hải Phòng chưa được đề cập nhiều [3,17-19]. Vì vậy, để làm rõ hơn lịch sử phát triển trầm tích Holocen của châu thổ sông Hồng cần nghiên cứu chi tiết vùng ven biển Hải Phòng. Hơn nữa, hầu hết các nghiên cứu về châu thổ sông Hồng nói chung và vùng ven biển Hải Phòng nói riêng ít đề cập đến kết quả nghiên cứu Diatomeae trong quá trình luận giải môi trường thành tạo trầm tích cũng như các vấn đề liên quan $[1,7,9,17,18]$. Để giải quyết vấn đề liên quan đến môi trường thành tạo trầm tích, nhóm Diatomeae được coi là một trong những công cụ hữu hiệu được nhiều tác giả sử dụng. Các môi trường ven biển cổ và các đường bờ biển cổ được vạch ra thông qua nghiên cứu sự thay đổi trong thành phần cũng như phân bố của nhóm này $[4,10,11$, 20-26]. Ở Việt Nam, Diatomeae đã được dùng như một phương pháp hữu hiệu trong việc xác lập lại lịch sử phát triển của đồng bằng sông Mekong $[11,13,14]$, đồng bằng ven biển miền Trung [27,28].

Trong bài báo này, sự thay đổi môi trường trầm tích trong Holocen tại vùng ven biển Hải Phòng sẽ được sáng tỏ trên cơ sở nghiên cứu chi tiết đặc điểm, sự phân bố các phức hệ Diatomeae và đặc điểm trầm tích tại lỗ khoan HP1 (Dương Kinh, Hải Phòng).

\section{Cơ sở tài liệu và phương pháp nghiên cứu}

\subsection{Cơ sở tài liệu}

100 mẫu Diatomeae và 74 mẫu độ hạt của lỗ khoan HP1 với chiều dài $23,6 \mathrm{~m}$ thuộc quận Dương Kinh, thành phố Hải Phòng $\left(20^{\circ} 49^{\prime} 16^{\prime \prime}\right.$ VĐ Bắc/106 $41^{\prime}$ 54.51"KĐ Đông-Hình 1) đã được thu thập, phân tích.

\subsection{Phuơng pháp nghiên cúu}

Phương pháp gia công và phân tích Diatomeae: mẫu được ngâm trong $\mathrm{H}_{2} \mathrm{O}_{2}$ và $\mathrm{HCl}$ nhằm tẩy hợp chất hữu cơ và cacbonat, tẩy sét bằng Pyrophotphatnatri trước khi ly tâm, làm giàu bằng dung dịch nặng [29]. Diatomeae được phân tích dưới kính hiển vi sinh vật (Carl Zeiss) có độ phóng đại $x 400$ và $x 1000$, được chụp ảnh bằng phần mềm Optikacam. Các tài liệu sử dụng xác định Diatomeae gồm Jouse (1977), Round F.E. (1990), Truong Ngoc An (1993), Hasle G. R (1996), S.R. Stidoiph et. al. (2012), Nguyen Thi Thu Cuc (2015) [30-35]. Diatomeae tìm thấy được thống kê trong 5 tiêu bản và tính tỷ lệ phần trăm cho từng loài gặp trong mẫu so với tương quan tổng số các mảnh vỏ gặp được trong mẫu. Các kết quả thu được được xử lý bằng phần mềm Excel và biểu đồ C2 [36]. Các nhóm Diatomeae được phân chia dựa vào độ muối (mặn, lợ và nước ngọt- [37,32]), kiểu sống (trôi nổi, bám đáy) và đặc điểm phân bố (đại dương, ngoài khơi, biển ven bờ hay duyên hải). Sự thay đổi hàm lượng (tần suất gặp) của các nhóm Diatomeae trong lỗ khoan là cơ sở phân chia các đới Diatomeae [13,14,35].

Phương pháp phân tích độ hạt được sử dụng nhằm xác định kích thước hạt trung bình $(\mathrm{Md})$, độ chọn lọc (So), hệ số bất đối xứng (Sk). Nguyên tắc cơ bản là phân chia trầm tích thành các cấp hạt khác nhau bằng bộ rây tiêu chuẩn $\sqrt[10]{10}$ và phương pháp pipet. Kích thước cấp hạt cát, bột và sét theo hệ thống phân loại của Cục địa chất Hoàng Gia Anh $[38,39]$. Dựa vào hàm lượng cát-bột- sét có mặt trong mẫu được thống kê trên phần mềm excel sau đó vẽ biểu đồ và phân chia thành các tập trầm tích dựa trên sự thay đổi của thành phần các cấp hạt trong lỗ khoan. 


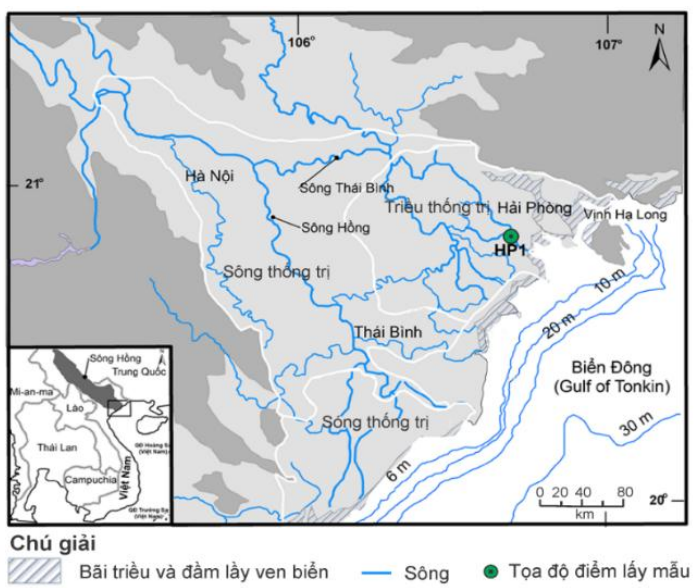

Hình 1. Sơ đồ vị trí lỗ khoan nghiên cứu (vẽ lại theo K. Hori và CS, 2004).

Phương pháp xác định hình thái hạt vụn: Hình thái hạt vụn được thể hiện qua hệ số mài tròn $(\mathrm{Ro})$ của các hạt vụn có cỡ hạt từ cát trở lên. Giá trị Ro thay đổi từ 0 đến 1 , Ro tăng thì độ mài tròn tăng. Các mẫu với hàm lượng cát chiếm trên $33 \%$ được chọn để tính giá trị Ro. Hệ số Ro chỉ có ý nghĩa với mẫu có hàm lượng cát cao, không có ý nghĩa đối với các mẫu có chứa hàm lượng bột, sét cao [38]. Cách tính là đếm các góc lồi của hạt vụn có mặt trong mẫu thông qua phân tích lát mỏng, chụp ảnh dưới kính hiển vi sau đó xác định, tính toán trên 100 hạt và lấy trị số trung bình. Khi số góc lồi lớn hơn 10: Hạt rất góc cạnh, góc lồi bằng 9 (chưa mài tròn, $R \mathrm{o}=0,1$ ), khi góc lồi bằng 0 thì độ mài tròn đạt lý tưởng hạt rất tròn cạnh $(\mathrm{Ro}=1)$. Số góc lồi càng ít thì độ mài tròn càng tốt, khi hạt vụn đạt tới độ mài tròn lý tưởng thì Ro $=1(\max )$. Giá trị Ro phản ánh môi trường thành tạo trầm tích: Ro= 0-0,5 (môi trường lục địa), Ro=0,5-0,7 (môi trường biển nông ven bờ), Ro=0,7-1,0 (môi trường ven biển) [38].

Phương pháp cổ sinh thái: Phương pháp cổ sinh thái là phương pháp nghiên cứu mối quan hệ giữa sinh vật cồ và môi trường sống của chúng. Những thay đổi về điều kiện môi trường (nhiệt độ, độ muối,...) dẫn đến sự thay đổi cấu trúc của các quần thể sinh vật $[35,40,41]$. Nghiên cứu sự thay đổi liên tục thành phần trong các mặt cắt địa chất cho phép khôi phục lại diễn biến của môi trường theo thời gian $[35,40]$.

\section{Kết quả và thảo luận}

\section{1. Đặc điểm thành phần và phân bố Diatomeae}

\subsubsection{Thành phần giống loài}

52 loài thuộc 21 giống Diatomeae trong trầm tích Holocen khu vực nghiên cứu đã được xác định, trong đó có 24 loài thuộc phụ lớp Diatomeae lông chim (Pennatophyceae) và 28 loài thuộc phụ lớp Diatomeae trung tâm (Centrophyceae). Thành phần giống loài Diatomeae trong trầm tích Holocen khu vực nghiên cứu tương đối đa dạng, tuy nhiên phần trăm tỷ lệ các loài ở mỗi giống là rất khác nhau trong từng mẫu, trong đó giống Coscinodiscus xuất hiện tới 10 loài Thalassiosira, Campylodiscus và Eunotia lần lượt có 5,4 và 3 loài được tìm thấy; Actinocyclus, Cyclotella, Triceratium và Diploneis có 2 loài; với các giống còn lại chỉ tìm thấy 1 loài (Bảng 1).

\subsection{2. Đặc điểm sinh thái Diatomeae trong} trầm tích Holocen vùng nghiên cứu

Trong vùng nghiên cứu, bốn nhóm sinh thái gồm: Diatomeae biển trôi nổi (MP), Diatomeae nước lợ trôi nổi (MBP), Diatomeae nước lợ bám đáy $(\mathrm{MBB})$ và Diatomeae nước ngọt $(\mathrm{F})$ đã được xác lập dựa trên đặc điểm sinh thái - môi trường sống (nước mặn, nước lợ, nước ngọt); kiểu sống (trôi nổi, bám đáy) hoặc vùng phân bố (đại dương, gần bờ, duyên hải, lục địa) của các loài Diatomeae đã được phát hiện. Trong số 52 loài Diatomeae gặp được trong iỗ khoan HP1 có 21 loài thích nghi với kiểu sống trôi nổi trong môi trường biển (MP), 14 loài thích nghi với kiểu sống trôi nổi trong vùng nước lợ ven bờ có độ muối thay đổi (nước lợ trôi nổi_MBP); 11 loài thích nghi với kiểu sống bám đáy trong vùng nước lợ ven bờ (nước lợ bám đáy_MBB) và 6 loài nước ngọt $(\mathrm{F})$ (Hình 2, Bảng 1$)$. Trầm tích có sự đa dạng về thành phần giống loài Diatomeae nhất được thấy ở độ sâu $1,81 \mathrm{~m}$. Tại đây có mặt 34 loài Diatomeae, trong đó 12 loài thuộc nước mặn trôi nổi chiếm $35 \%$ số loài trong mẫu, 11 loài thuộc nước lợ trôi nổi chiếm 32\%, 7 loài thuộc nước lợ bám đáy chiếm $21 \%$ và 4 loài thuộc nước ngọt chiếm 12\% (Hình 2). 
Kết quả nghiên cứu cho thấy Diatomeae trôi nổi chiếm số lượng lớn nhưng số lượng mảnh vỏ gặp trong trầm tích có tỉ lệ thấp, nằm rải rác theo chiều dọc lỗ khoan, đặc biệt các mảnh vụn Coscinodiscus gặp tại hầu hết các mẫu có Diatomeae. Các loài nước lợ trôi nổi phổ biến trong toàn bộ các mẫu chứa Diatomeae, đặc biệt là hai loài Cyclotella striata (Ảnh 1) và $C y c$. stylorum (Ảnh 2). Paralia sulcata (Ảnh 3) cũng có mặt cùng với hai loài Cyclotella nói trên nhưng số lượng các mảnh vỏ ít hơn. Các loài Diatomeae nước lợ bám đáy ít gặp cả về thành phần giống loài lẫn số lượng cá thể. Diatomeae nước ngọt gặp với số lượng rất ít cả về số lượng cá thể lẫn thành phần giống loài (Bảng 1).

3.1.3. Các đới sinh thái Diatomeae trong lỗ khoan HP1, Dưong Kinh, Hải Phòng

Biểu đồ phân bố Diatomeae theo cột lỗ khoan được xây dựng dựa trên thành phần giống loài, đặc điểm sinh thái, phần trăm số lượng mảnh vỏ Diatomeae của từng mẫu (Hình 3 ). Sự phân bố Diatomeae cả về thành phần giống loài, số lượng mảnh vỏ và các nhóm sinh thái thể hiện trên biểu đồ là cơ sở để phân chia trầm tích Holocen khu vực nghiên cứu thành các đới sinh thái Diatomeae (ecodiatom zone) như sau: DIAHPZ1， DIA-HPZ2， DIA-HPZ3， DIA-HPZ4, DIA-HPZ5

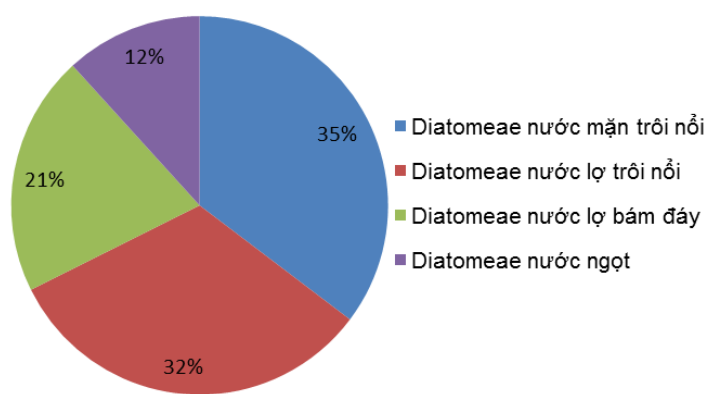

Hình 2. Biểu đồ các nhóm sinh thái Diatomeae tại độ sâu 1,81m lỗ khoan HP1.

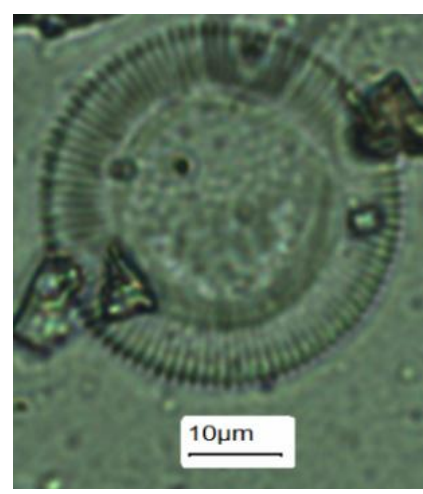

Ảnh 1. Cyclotella striata Grunow (mẫu HP1-1.01m)

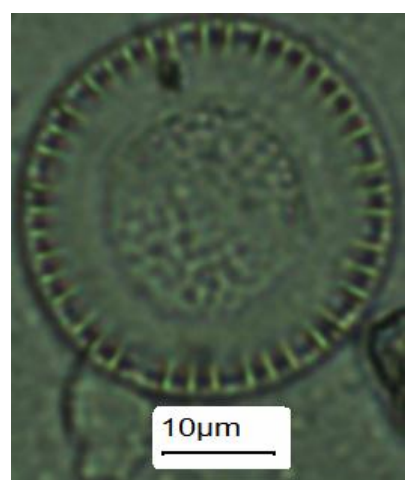

Ảnh 2.Cyclotella stylorumBrightwel (mẫu HP1- 1.01m)

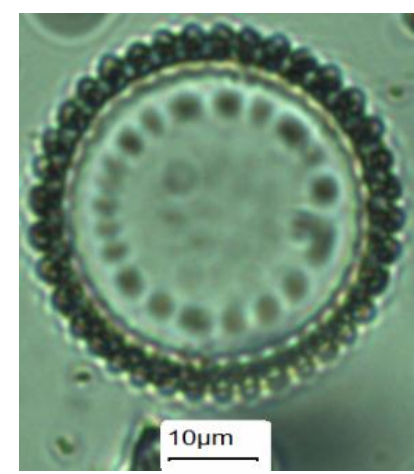

Ảnh 3. Paralia sulcata (Ehrenberg) Cleve (mẫu HP1-5.06m)
Đới 1: DIA-HPZ1, độ sâu phân bố: 23,512,4m (Hình 3), đặc trưng bởi sự vắng mặt hoặc hiếm gặp Diatomeae. Trong đới này, chỉ gặp một vài mảnh vụn của Cyclotella stylorum tại độ sâu $21,06 \mathrm{~m}$ và Coscinodiscus sp. tại độ sâu 16,19 và 16,56m (Bảng 1). Còn các mẫu khác không gặp Diatomeae.

Đới 2: DIA-HPZ2, độ sâu phân bố: 12,4$10,0 \mathrm{~m}$, đặc trưng bởi sự xuất hiện rải rác
Diatomeae trong đới với số lượng nhiều hơn so với đới 1 (Hình 3 ). Tại độ sâu 12,4 và $12,35 \mathrm{~m}$ gặp một số loài Diatomeae với số lượng không nhiều gồm Coscinodiscus perforatus, Cyclotella stylorum, Campylodiscus sp.. Ngoài ra, tại độ sâu $10,83 \mathrm{~m}$ và $10,22 \mathrm{~m}$ cũng gặp Diatomeae gồm Cyclotella striata, Coscinodiscus perforatus, Coscinodiscus sp., Diploneis smithii, Paralia sulcata nhưng số lượng không nhiều (Bảng 1 , Hình 3). 
Bảng 1. Thành phần loài, đặc điểm sinh thái và số lượng mảnh vỏ Diatomeae trong các mẫu tại lỗ khoan HP1-Dương Kinh, Hải Phòng

\begin{tabular}{|c|c|c|c|c|c|c|c|c|c|c|c|c|c|c|c|}
\hline \multirow{2}{*}{ STT } & \multirow{2}{*}{ Tên loài } & \multirow{2}{*}{\multicolumn{2}{|c|}{\begin{tabular}{c|c|} 
Phân & Đặc điểm \\
loại & sinh thái \\
\end{tabular}}} & \multicolumn{12}{|c|}{ Độ sâu mẫu có Diatomeae trong lỗ khoan (m) } \\
\hline & & & & 0.08 & 0.23 & 0.41 & 0.82 & 1.01 & 1.81 & 2.01 & 2.11 & 2.21 & 2.43 & 3.01 & 3.11 \\
\hline 1. & $\begin{array}{l}\text { Actinocyclus } \\
\text { divisus }\end{array}$ & $\mathrm{C}$ & MP & & & & & & 1 & & & & & & \\
\hline 2. & $\begin{array}{l}\text { Actinocyclus } \\
\text { ehrenbergii }\end{array}$ & $\mathrm{C}$ & MBP & & & & & 2 & 9 & & 2 & 1 & 3 & & \\
\hline 3. & $\begin{array}{l}\text { Actinocyclus } \\
\text { ellipticus }\end{array}$ & $\mathrm{C}$ & MBP & & & & & & & & & & & & 1 \\
\hline 4. & $\begin{array}{l}\text { Actinoptychus } \\
\text { undulatus }\end{array}$ & $\mathrm{C}$ & MP & & & & & & 1 & & & & & & \\
\hline 5. & $\begin{array}{l}\text { Caloneis } \\
\text { formosa }\end{array}$ & $\mathrm{P}$ & $\mathrm{MBB}$ & & & & & & 1 & 2 & & & 1 & & \\
\hline 6. & $\begin{array}{l}\text { Campylodiscus } \\
\text { daemelianus }\end{array}$ & $\mathrm{P}$ & MBP & 3 & & & & & 1 & & & 1 & 1 & & \\
\hline 7. & \begin{tabular}{|l|} 
Campylodiscus \\
echeneis
\end{tabular} & $\mathrm{P}$ & MBP & & & & & 3 & & & & & & & \\
\hline 8. & Campylodiscus sp. & $\mathrm{P}$ & MBP & & & & & & 1 & 2 & 1 & & 5 & & \\
\hline 9. & $\begin{array}{l}\text { Campylodiscus } \\
\text { undulatus }\end{array}$ & $\mathrm{P}$ & MBP & & & & & 2 & 1 & & 4 & & 6 & & \\
\hline 10. & $\begin{array}{l}\text { Campyloneis } \\
\text { aff. notabilis }\end{array}$ & $\mathrm{P}$ & MBP & & & & & & 1 & & & & & & \\
\hline 11. & Cocconeis sp. & $\mathrm{P}$ & $\mathrm{MBB}$ & & & & & & 1 & & & & 1 & & \\
\hline 12. & $\begin{array}{l}\text { Coscinodiscus } \\
\text { asteromphalus }\end{array}$ & $\mathrm{C}$ & MP & & & & & & 1 & & & & & & \\
\hline 13. & $\begin{array}{l}\text { Coscinodiscus } \\
\text { gigas }\end{array}$ & $\mathrm{C}$ & MP & & & & & & 1 & & & & & & \\
\hline 14. & $\begin{array}{l}\text { Coscinodiscus } \\
\text { lacustris }\end{array}$ & $\mathrm{C}$ & MBP & & & & & 1 & 2 & & & & 3 & & \\
\hline 15. & $\begin{array}{l}\text { Coscinodiscus } \\
\text { lineatus }\end{array}$ & $\mathrm{C}$ & MP & 1 & & & & 4 & 5 & 1 & 2 & & 3 & 7 & \\
\hline 16. & \begin{tabular}{|l|} 
Coscinodiscus \\
marginatus
\end{tabular} & $\mathrm{C}$ & MP & & & & & & & 1 & & & & & \\
\hline 17. & $\begin{array}{l}\text { Coscinodiscus } \\
\text { oculus-iridis }\end{array}$ & $\mathrm{C}$ & MP & & & & & & & & & & 2 & & \\
\hline 18. & $\begin{array}{l}\text { Coscinodiscus } \\
\text { perforatus }\end{array}$ & $\mathrm{C}$ & MP & 1 & & & & & 2 & & 3 & 1 & 5 & 3 & \\
\hline 19. & $\begin{array}{l}\text { Coscinodiscus } \\
\text { pseudoincertus }\end{array}$ & $\mathrm{C}$ & MP & 1 & & & & & & & & & & & \\
\hline 20 . & $\begin{array}{l}\text { Coscinodiscus } \\
\text { radiatus }\end{array}$ & $\mathrm{C}$ & MP & & & & & & 1 & & 2 & & 1 & & \\
\hline 21. & Coscinodiscus sp. & $\mathrm{C}$ & MP & & & 3 & 2 & 2 & 18 & 2 & 15 & 1 & 3 & 2 & 1 \\
\hline 22. & \begin{tabular}{|l|} 
Coscinodiscus \\
subtilis \\
\end{tabular} & $\mathrm{C}$ & MP & & & & & & & & & & 1 & & \\
\hline 23. & Cyclotella striata & $\mathrm{C}$ & MBP & 3 & 21 & 23 & 12 & 50 & 40 & 37 & 150 & 1 & 132 & 56 & 1 \\
\hline 24. & $\begin{array}{l}\text { Cyclotella } \\
\text { stylorum }\end{array}$ & $\mathrm{C}$ & MBP & 8 & 13 & & 7 & 20 & 56 & 19 & 102 & 3 & 67 & 13 & 5 \\
\hline 25. & Diploneis smithii & $\mathrm{P}$ & MBB & & & & & 3 & 2 & 2 & 5 & & 2 & & \\
\hline
\end{tabular}




\begin{tabular}{|c|c|c|c|c|c|c|c|c|c|c|c|c|c|c|c|}
\hline \multirow{2}{*}{ STT } & \multirow{2}{*}{ Tên loài } & \multirow{2}{*}{$\begin{array}{c}\text { Phân } \\
\text { loại }\end{array}$} & \multirow{2}{*}{$\begin{array}{l}\text { Đặc điểm } \\
\text { sinh thái }\end{array}$} & \multicolumn{12}{|c|}{ Độ sâu mẫu có Diatomeae trong lỗ khoan (m) } \\
\hline & & & & 0.08 & 0.23 & 0.41 & 0.82 & 1.01 & 1.81 & 2.01 & 2.11 & 2.21 & 2.43 & 3.01 & 3.11 \\
\hline 26. & Diploneis sp. & $\mathrm{P}$ & MBB & 1 & & & & & & & & & & & \\
\hline 27. & Eunotia clevei & $\mathrm{P}$ & $\mathrm{F}$ & & & & & & & & & & 1 & & \\
\hline 28. & $\begin{array}{l}\text { Eunotia } \\
\text { pectinalis }\end{array}$ & $\mathrm{P}$ & $\mathrm{F}$ & 5 & & & & & 1 & 2 & 6 & & & & \\
\hline 29. & Eunotia sp. & $\mathrm{P}$ & $\mathrm{F}$ & 9 & & & & & 1 & & & & & & \\
\hline 30. & Gomphonema sp. & $\mathrm{P}$ & $\mathrm{F}$ & 1 & & & & & 1 & 1 & & & 2 & & \\
\hline 31. & $\begin{array}{l}\text { Hyalodiscus } \\
\text { scoticus }\end{array}$ & $\mathrm{C}$ & MBP & & & & & & & & & & 1 & & \\
\hline 32. & $\begin{array}{l}\text { Navicula } \\
\text { glacialis }\end{array}$ & $\mathrm{P}$ & MBB & & & & & 2 & 4 & & & & 2 & & \\
\hline 33. & Navicula sp. & $\mathrm{P}$ & MBB & 1 & & & & & 1 & & & & & & \\
\hline 34. & $\begin{array}{l}\text { Nitzschia } \\
\text { cocconeiformis }\end{array}$ & $\mathrm{P}$ & MBB & 1 & 8 & & & 3 & 9 & 2 & 3 & & 3 & 5 & \\
\hline 35. & Nitzschia sicula & $\mathrm{P}$ & MBP & & & & & & 1 & & & & & & \\
\hline 36. & $\begin{array}{l}\text { Nitzschia } \\
\text { panduriformis }\end{array}$ & $\mathrm{P}$ & MBB & & & & & & & & & & 2 & & \\
\hline 37. & Nitzschia sp. & $\mathrm{P}$ & MBB & 1 & & & & & & & & & & & \\
\hline 38. & Paralia sulcata & $\mathrm{C}$ & MBP & & 9 & & 3 & 10 & 6 & 13 & 23 & & 32 & 14 & 1 \\
\hline 39. & Pinnularia sp. & $\mathrm{P}$ & $\mathrm{F}$ & & & & & & 1 & & & & & & \\
\hline 40. & Planktoniella sol & $\mathrm{C}$ & MP & & & & & & 3 & & & & & & \\
\hline 41. & $\begin{array}{l}\text { Rhizosolenia } \\
\text { styliformis }\end{array}$ & $\mathrm{C}$ & MP & & & & & & 2 & & & & & & 1 \\
\hline 42. & Synedra sp. & $\mathrm{P}$ & $\mathrm{F}$ & 1 & & & & & & & & & & & \\
\hline 43. & $\begin{array}{l}\text { Thalassiosira } \\
\text { excentrica }\end{array}$ & $\mathrm{C}$ & MP & 1 & & & & & & & & & & & \\
\hline 44. & $\begin{array}{l}\text { Thalassiosira } \\
\text { oestrupii }\end{array}$ & $\mathrm{C}$ & MP & & & & & & 1 & & 4 & & & & \\
\hline 45. & $\begin{array}{l}\text { Thalassiosira } \\
\text { pacifica }\end{array}$ & $\mathrm{C}$ & MP & & & & & & 3 & & & 1 & & & 1 \\
\hline 46. & $\begin{array}{l}\text { Thalassiosira } \\
\text { polychorda }\end{array}$ & $\mathrm{C}$ & MP & & & & & & & & & & 1 & & \\
\hline 47. & $\begin{array}{l}\text { Thalassionema } \\
\text { nitzschioides }\end{array}$ & $\mathrm{P}$ & MBP & & & & & & 1 & & & & 1 & & \\
\hline 48. & Trachyneis aspera & $\mathrm{P}$ & MBB & & & & & & & & & & 6 & & \\
\hline 49. & Trachyneis debyi & $\mathrm{P}$ & MBB & & & & & & 1 & & & & & & \\
\hline 50. & Triceratium favus & $\mathrm{C}$ & MP & & & & & & & & & & 2 & & \\
\hline 51. & Tricetratium sp. & $\mathrm{C}$ & MP & & & & & 1 & & & & & & & \\
\hline & $\begin{array}{l}\text { Tổng số mảnh vỏ } \\
\text { trên } 5 \text { lát mỏng }\end{array}$ & & & 39 & 51 & 26 & 24 & 103 & 177 & 84 & 322 & 9 & 293 & 100 & 11 \\
\hline
\end{tabular}

Chú thích: C: Diatomeae trung tâm, P: Diatomeae lông chim, MP: Diatomeae biển trôi nổi (Diatom sống trôi nổi trong môi trường độ muối $>30 \%$ ), MBP: Diatomeae nước lợ trôi nổi (Diatomeae sống trôi nổi trong môi trường có độ muối 2-30\%o ), MBB: Diatomeae nước lợ bám đáy (Diatomeae sống bám đáy trong môi trường có độ muối 2-30\%), F: Diatomeae nước ngọt (Diatomeae sống ở nơi có độ muối nhỏ hơn $2 \%$ ) $[36,42,43]$. 
Bảng 1. Thành phần loài, đặc điểm sinh thái và số lượng mảnh vỏ Diatomeae trong các mẫu tại lỗ khoan HP1-Dương Kinh, Hải Phòng (tiếp)

\begin{tabular}{|c|c|c|c|c|c|c|c|c|c|c|c|c|c|c|c|}
\hline \multirow[b]{2}{*}{ STT } & \multirow[b]{2}{*}{ Tên loài } & \multirow[b]{2}{*}{$\begin{array}{l}\text { Phân } \\
\text { loại }\end{array}$} & \multirow{2}{*}{\begin{tabular}{|c|} 
Đặc \\
điểm \\
sinh \\
thái \\
\end{tabular}} & \multicolumn{12}{|c|}{ Độ sâu mẫu có Diatomeae trong lỗ khoan (m) } \\
\hline & & & & 3.71 & 4.47 & 4.67 & 4.86 & 5.06 & 5.56 & 10.22 & 10.83 & 12.35 & 12.4 & 16.56 & 21.06 \\
\hline 2 & Actinocyclus ehrenbergii & $\mathrm{C}$ & MBP & & 2 & & & & & & & & & & \\
\hline 8 & Campylodiscus sp. & $\mathrm{P}$ & MBP & & & & & & & 1 & & 3 & & & \\
\hline 13 & Coscinodiscus gigas & $\mathrm{C}$ & MP & & & & 1 & & & & 2 & & & & \\
\hline 15 & Coscinodiscus lineatus & $\mathrm{C}$ & MP & & 3 & & & 1 & & & & & & & \\
\hline 16 & Coscinodiscus marginatus & $\mathrm{C}$ & MP & & 2 & & & & & & & & & & \\
\hline 18 & Coscinodiscus perforatus & $\mathrm{C}$ & MP & & & 2 & 2 & & & & & 2 & 1 & & \\
\hline 18 & $\begin{array}{l}\text { Coscinodiscus } \\
\text { pseudoincertus }\end{array}$ & $\mathrm{C}$ & MP & & 2 & & & & & & & & & & \\
\hline 21 & Coscinodiscus sp. & $\mathrm{C}$ & MP & 2 & 5 & 3 & & 3 & & 2 & & & 1 & 2 & \\
\hline 22 & Coscinodiscus subtilis & $\mathrm{C}$ & MP & & 2 & & & & & & & & & & \\
\hline 23 & Cyclotella striata & $\mathrm{C}$ & MBP & 4 & 152 & & & 19 & 5 & 25 & & & 5 & & \\
\hline 24 & Cyclotella stylorum & $\mathrm{C}$ & MBP & 2 & 57 & & & 5 & 2 & 3 & & 3 & 1 & & 3 \\
\hline 25 & Diploneis smithii & $\mathrm{P}$ & MBB & & 2 & & & & & 2 & & & & & \\
\hline 34 & Nitzschia cocconeiformis & $\mathrm{P}$ & MBB & & 8 & 3 & & & & 2 & & & & & \\
\hline 38 & Paralia sulcata & $\mathrm{C}$ & MBP & & 13 & & & 17 & & 3 & & & 1 & & \\
\hline 43 & Thalassiosira excentrica & $\mathrm{C}$ & MP & & 3 & & & & & & & & & & \\
\hline \multirow[t]{2}{*}{47} & Thalassiosira sp. & $\mathrm{C}$ & MP & & 2 & & & & & & & & & & \\
\hline & $\begin{array}{l}\text { Tổng số mảnh vỏ } \\
\text { trên } 5 \text { lát mỏng }\end{array}$ & & & 8 & 253 & 8 & 3 & 45 & 7 & 38 & 2 & 8 & 9 & 2 & 3 \\
\hline
\end{tabular}

Chú thích: C: Diatomeae trung tâm, P: Diatomeae lông chim, MP: Diatomeae biển trôi nổi (Diatom sống trôi nổi trong môi trường độ muối $>30 \%$ ), MBP: Diatomeae nước lợ trôi nổi (Diatomeae sống trôi nổi trong môi trường có độ muối 2-30\%), MBB: Diatomeae nước lợ bám đáy (Diatomeae sống bám đáy trong môi trường có độ muối 2-30\%), F: Diatomeae nước ngọt (Diatomeae sống ở nơi có độ muối nhỏ hơn 2\%o) [36,42,43].

Đới 3: DIA-HPZ3, độ sâu phân bố: 10,0$5,6 \mathrm{~m}$, đặc trưng bởi sự vắng mặt hoàn toàn Diatomeae trong trầm tích (Hình 3).

Đới 4: DIA-HPZ4, độ sâu phân bố: 5,6-3,2m, đặc trưng bởi sự xuất hiện rải rác của Diatomeae trong toàn bộ đới (Bảng 1). Đặc trưng của đới là số lượng giống loài Diatomeae không nhiều, ngoại trừ mẫu $4,47 \mathrm{~m}$ rất giàu với số lượng lên tới 253 mảnh vỏ tìm được trên 5 lát mỏng. Các mẫu chứa Diatomeae thuộc ba nhóm sinh thái: biển trôi nổi, nước lợ trôi nổi, nước lợ bám đáy. Nhóm Diatomeae nước ngọt hoàn toàn vắng mặt. Nhóm Diatomeae biển trôi nổi gặp chủ yếu là một vài mảnh vỏ thuộc giống Coscinodiscus với số lượng hạn chế (Bảng 1). Nhóm Diatomeae nước lợ trôi nổi gồm Cyclotella striata, Cyclotella stylorum và Paralia sulcata là chủ yếu, trong đó Cyclotella striata có số lượng vỏ gặp được nhiều nhất (Bảng 1). Trong đới này, số lượng Diatomeae nước lợ bám đáy cũng xuất hiện nhiều hơn đới DIA-HPZ2, với sự có mặt của các loài Diploneis smithii, Nitzschia cocconeiformis. Riêng tại độ sâu 4,47m gặp được số lượng lớn Diatomeae với sự vượt trội của Diatomeae nước lợ trôi nổi Cyclotella striata, Cyclotella stylorum và Paralia sulcata, chiếm tỷ lệ $89 \%$ trong mẫu. Ở độ sâu này Cyclotella striata chiếm tỷ lệ $60 \%$ trong mẫu (Hình 3), vì thế đây là loài tại chỗ.

Đới 5: DIA-HPZ5 độ sâu phân bố 3,2-0m. Tại đới này xuất hiện đầy đủ phức hệ Diatomeae 
thuộc 4 nhóm sinh thái (Hình 3). Tổng số lượng mảnh vỏ Diatomeae gặp trong trầm tích giảm dần theo chiều từ dưới lên, cùng với đó là sự giảm dần tỉ lệ mảnh vỏ của các loài Diatomeae biển trôi nổi và nước lợ trôi nổi, tăng dần tỷ lệ của Diatomeae nước ngọt. Trong đới này Cyclotella stylorum vẫn là loài chiếm ưu thế về số lượng mảnh vỏ nhưng đã giảm còn khoảng 40-50\%.

Trong đới sinh thái này các loài thuộc nhóm nước lợ bám đáy xuất hiện với tần suất nhiều hơn đới DIA-HPZ4 như Caloneis formosa, Diploneis smithii, Navicula glacialis, Nitzschia cocconeiformis, Nitzschia panduriformis, Trachyneis aspera,... Cùng với đó là sự xuất hiện của các loài Diatomeae nước ngọt với tỉ lệ thay đổi theo hướng tăng dần từ dưới lên, từ $2-5 \%$ đến gần $40 \%$ số mảnh vỏ trong trầm tích. Các loài Diatomeae nước ngọt chủ yếu gồm Eunotia clevei, Eunotia pectinalis, Gomphonema sp., Pinnularia sp.,...Đới này khác biệt với các đới DIA-HPZ2 và DIA-HPZ4 bởi sự giảm dần của Diatomeae biển trôi nổi, nước lợ trôi nổi và tăng dần của Diatomeae nước lợ bám đáy và nước ngọt (Bảng 1, Hình 3).

\section{2. Đặc điểm trầm tích}

Trên cơ sở đặc điểm thành phần độ hạt, tương quan hàm lượng cát - bột - sét và đặc điểm về màu sắc, cấu tạo, trầm tích trong lỗ khoan HP1 được phân chia thành 7 tập $(Z)$ từ dưới lên như sau (Hình $4 a, b$ ):

Tập $1\left(\mathrm{Z}_{1}\right)(23,5-22,1 \mathrm{~m})$ đặc trưng bởi sự có mặt của cả ba thành phần cát, bột và sét, trong đó cát chiếm $12-52 \%$, bột $20-34 \%$, sét $28-62 \%$. Trầm tích có màu nâu, màu xám nâu chuyển sang xám sẫm chứa các vón cuội sét (Hình $4 b$ ). Trầm tích tập $Z_{1}$ phủ trực tiếp trên trầm tích loang lổ tuổi Pleistocen.

Tập $2\left(Z_{2}\right)(22,1 \mathrm{~m}-20,2 \mathrm{~m})$ với thành phần sét chiếm ưu thế, nhưng trong trầm tích vẫn gặp ít cát, cụ thể cát chiếm từ 2 đến 13\%, bột 13-37\% và sét 51-63\%. Trầm tích màu xám sẫm, giàu vật chất hữu cơ (Hình $4 \mathrm{~b}$ ), trầm tích có xu hướng mịn dần từ dưới lên (Hình $4 \mathrm{a})$.

Tập $3\left(\mathrm{Z}_{3}\right)(20,2 \mathrm{~m}-18,8 \mathrm{~m})$ với thành phần trầm tích chủ yếu là sét (70-91\%), bột chỉ chiếm
9-29\%. Cát hoàn toàn vắng mặt tại tập này. Trầm tích có màu xám sẫm, đôi chỗ có chứa vật chất hữu cơ (Hình $4 b)$. Trầm tích tập $Z_{3}$ mịn hơn trầm tích tập $Z_{2}$ (Hình 4a).

Tập $4\left(\mathrm{Z}_{4}\right)(18,8 \mathrm{~m}-15,3 \mathrm{~m})$ phần này chứa hàm lượng cát rất nhỏ chiếm khoảng $0-7 \%$, bột 13-34\%, sét 66-81\% (Hình 4a). Trầm tích có màu xám sắc xanh, đôi chỗ có chứa vật liệu hữu cơ (Hình $4 \mathrm{~b})$. Như vậy, trầm tích đã có xu hướng thô hơn tập $Z_{3}$, bởi sự có mặt của cát, sét đã giảm tuy không nhiều so với tập $Z_{3}$.

Tập $5\left(\mathrm{Z}_{5}\right)(15,3 \mathrm{~m}-7,8 \mathrm{~m})$ với lượng cát gặp liên tục trong các điểm phân tích mẫu với hàm lượng dao động từ 1-9\%, bột dao động lớn từ 8$50 \%$ và sét $42-85 \%$ (Hình $4 \mathrm{a}$ ). Trầm tích màu xám sáng chuyển dần lên xám nâu, hạt thô hơn so với tập $Z_{4}$, có chứa một số mảnh vụn vỏ sò.

Tập $6\left(\mathrm{Z}_{6}\right)(7,8 \mathrm{~m}-3,2 \mathrm{~m})$ với hàm lượng cát tăng cao hơn hẳn các tập trước thay thế cho hàm lượng sét và biên độ dao động tương đối lớn (Hình $4 a$ ), cát chiếm từ $12-63 \%$, bột $20-58 \%$ và sét $15-42 \%$. Trầm tích có màu xám nâu nghèo vật liệu hữu cơ, có chứa vụn vỏ sò (Hình $4 b$ ), đôi chỗ có phân lớp sóng xiên.

Tập $7\left(\mathrm{Z}_{7}\right)(3,2 \mathrm{~m}-0 \mathrm{~m})$ đặc trưng bằng sự giảm đột ngột của cỡ hạt cát (6-13\%), bột chiếm thành phần trội hơn (29-86\%), sét 6-65\% (Hình 4a). Như vậy từ dưới lên trên hàm lượng các cấp hạt, cát, bột và sét thay đổi liên tục từ thô tới mịn và sau đó lại từ mịn tới thô rồi lại mịn hơn, một số chỗ có phân lớp ngang song song, một số phân lớp xiên chéo (Hình $4 b)$.

\section{3. Đặc điểm hình thái hạt vụn}

Các mẫu được lựa chọn phân tích hệ số mài tròn của hạt vụn là các mẫu có hàm lượng cát cao (>33\% cát). Các độ sâu lấy mẫu: 23,4-23,44m; $23,24-23,28 \mathrm{~m} ; 22,20-22,24 \mathrm{~m} ; 6,65-6,69 \mathrm{~m} ; 6,24-$ $6,28 \mathrm{~m} ; 5,22-5,26 \mathrm{~m}$ và $3,20-3,24 \mathrm{~m}$. Các hạt cát trong trầm tích có số lượng góc lồi chủ yếu là 3 , 4 và 5 (Hình 5 ). Kết quả xác định hệ số mài tròn (Ro) của hạt vụn có giá trị từ 0,57 đến 0,61 (Bảng 2), ứng với cấp mài tròn 4-độ mài tròn tương đối tốt trong bảng phân loại cấp mài tròn các đá vụn cơ học của Trần Nghi, 1999, phản ánh vật liệu trầm tích được hình thành ở khu vực biển nông ven bờ [38]. 


\subsection{Môi trường thành tạo trầm tích Holocen khu vục ven biển Hải Phòng}

Kết quả phân tích tảo Diatomeae và đặc điểm trầm tích cho phép phân chia môi trường trầm tích Holocen tại lỗ khoan HP1, Dương Kinh (thành phố Hải Phòng) thành bốn kiểu: estuaryvũng vịnh, chân châu thổ, tiền châu thổ và đồng bằng châu thổ (Hình 6$)$.

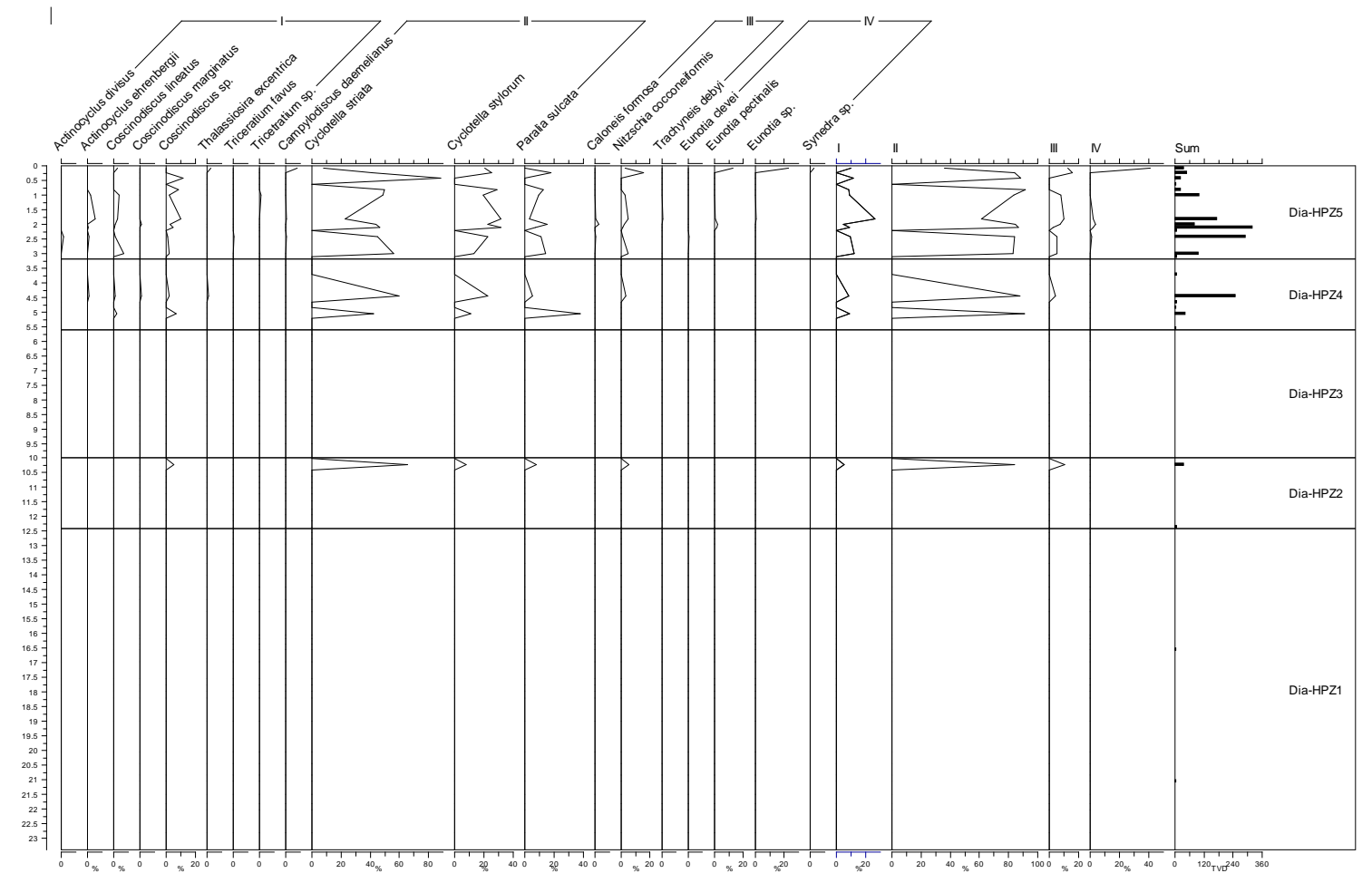

Hình 3. Biểu đồ phân bố Diatomeae và các đới sinh thái Diatomeae trong trầm tích Holocen tại lỗ khoan HP1 (Dương Kinh, Hải Phòng).

Chú giải: I: Diatomeae biển trôi nổi, II: Diatomeae nước lợ, trôi nổi, III: Diatomeae nước lợ, bám đáy; IV: Diatomeae nước ngọt. Sum: tổng số mảnh vỏ trên 5 tiêu bản.DIA-HPZ1, DIA-HPZ2, DIA-HPZ3, DIA-HPZ4, DIA-HPZ5: đới sinh thái Diatomeae (ecodiatom zone).

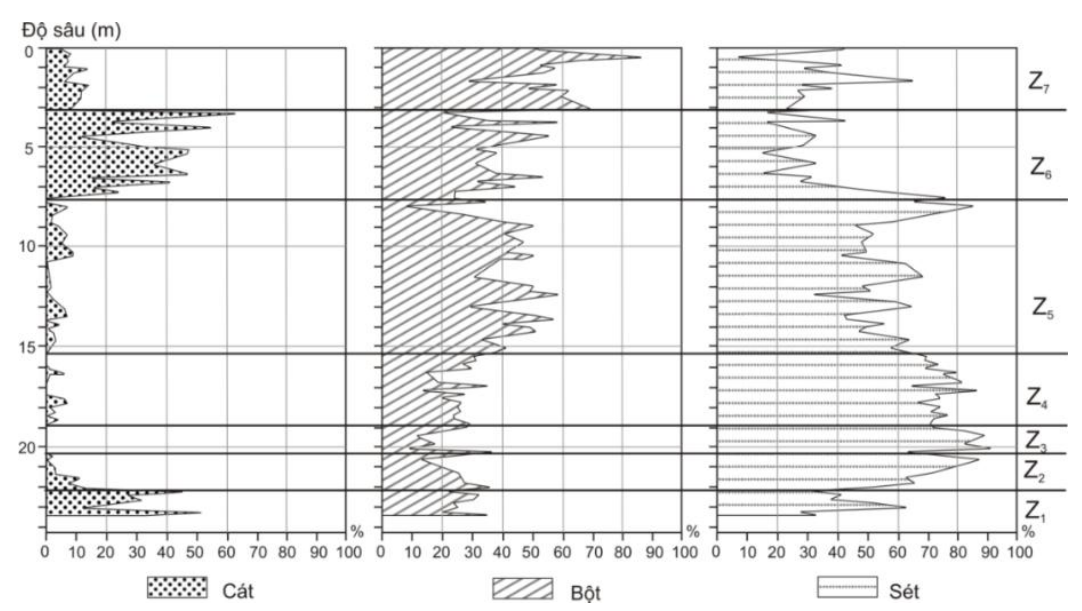

Hình 4a. Hàm lượng cát, bột và sét trong các tập trầm tích tại lỗ khoan HP1. 


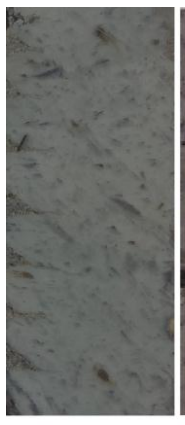

$\mathrm{Z}_{1}$

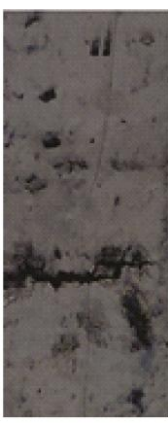

$\mathrm{Z}_{2}$

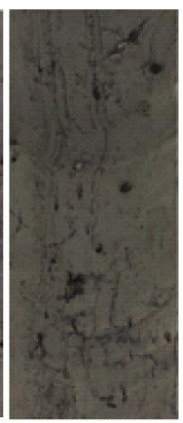

$\mathrm{Z}_{3}$

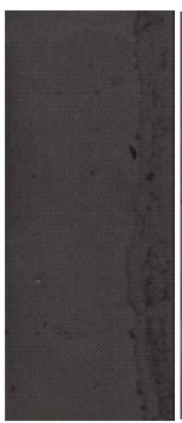

$\mathrm{Z}_{4}$

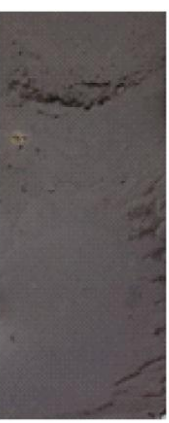

$\mathrm{Z}_{5}$

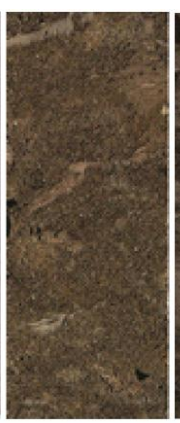

$Z_{6}$

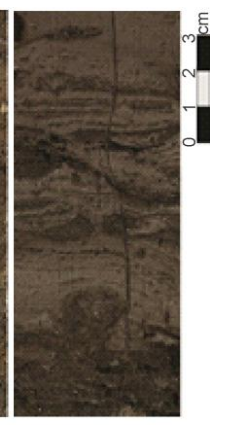

$\mathrm{Z}_{7}$

Hình 4b. Ảnh trầm tích trong các phân tập $\left(Z_{1}-Z_{7}\right)$, trong lỗ khoan HP1.

\subsubsection{Estuary-vũng vịnh}

Trầm tích estuary-vũng vịnh gặp ở độ sâu từ 23,5 đến 18,8m. Môi trường estuary-vũng vịnh thể hiện bởi sự thay đổi về đặc điểm trầm tích của các tập trầm tích $Z_{1}, Z_{2}$ và $Z_{3}$ và ứng với phần dưới của đới DIA-HPZ1.

Trầm tích tập $Z_{1}(23,5-22,1 \mathrm{~m})$ phủ trực tiếp lên tầng phong hóa loang lổ tuổi Pleistocen. Tập $\mathrm{Z}_{1}$ đặc trưng bởi sự đa dạng về thành phần trầm tích gồm cả cát, bột và sét, màu xám vàng, xám nâu chuyển lên xám sẫm chứa các cuội sét. Giá trị Ro của hạt cát trong khoảng 0,56-0,6 (Bảng 2) phản ánh trầm tích được hình thành trong môi trường biển nông ven bờ [38].

Tập $\mathrm{Z}_{2}(22,1 \mathrm{~m}-20,2 \mathrm{~m})$, trầm tích mịn hơn với thành phần chủ yếu là sét (Hình $4 \mathrm{a})$ chứa bột và ít cát, có màu xám sẫm chứa nhiều vật liệu hữu cơ (Hình 4b). Diatomeae rất hiếm gặp, chỉ gặp một số mảnh vỏ Cyclotella stylorum ở khoảng độ sâu 21,06m. Đây là loài Diatomeae trôi nổi sống trong vùng nước lợ, cửa sông, ven biển [20,21, 42,43].

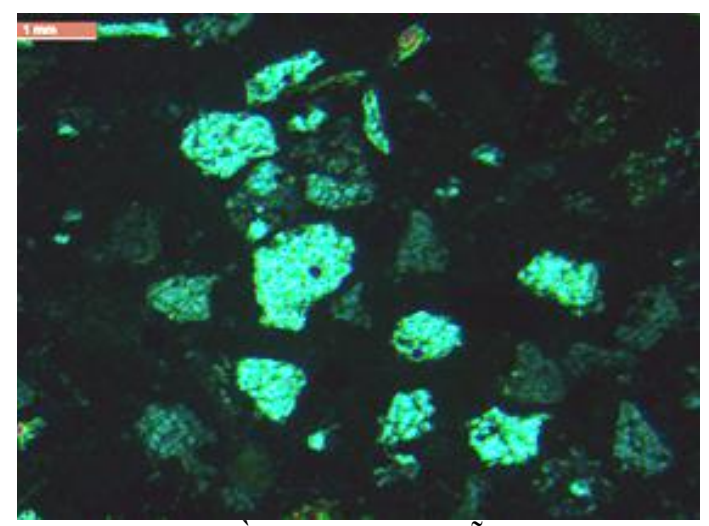

Hình 5. Trầm tích cát tại mẫu HP1 (6,65m-6,69m).
Bảng 2. Kết quả xác định độ mài tròn (Ro)

\begin{tabular}{|c|c|c|c|}
\hline TT & SHM & $\begin{array}{c}\text { Độ sâu tb } \\
(\mathrm{m})\end{array}$ & Ro \\
\hline 1 & HP1. 3,20-3,24 & 3,22 & 0,61 \\
\hline 2 & HP1. 5,22-5,26 & 5,24 & 0,57 \\
\hline 3 & HP1. 6,24-6,26 & 6,26 & 0,56 \\
\hline 4 & HP1. 6,65-6,69 & 6,67 & 0,5 \\
\hline 5 & HP1. 22,20-2,24 & 22,22 & 0,6 \\
\hline 6 & HP1. 23,24-23,28 & 23,26 & 0,56 \\
\hline 7 & HP1. 23,40-23,44 & 23,42 & 0,59 \\
\hline
\end{tabular}

Sự có mặt của loài này, tuy không nhiều nhưng cũng cho thấy môi trường thành tạo trầm tích liên quan tới biển. Trương Ngọc An, 1993 [32] khi nghiên cứu về tảo phù du biển Việt Nam thì cho rằng loài này mang tính biển ấm ven bờ, rộng nhiệt. Chính vì vậy, sự có mặt của loài này trong trầm tích phản ánh cho nhận định nói trên. Trầm tích hạt mịn, giàu vật liệu hữu cơ, có chứa Diatomeae nước lợ phản ánh môi trường đầm lầy ven biển [3].

Tập $Z_{3}(20,2 m-18,8 m)$, trầm tích có màu xám sắc xanh, sét chiếm ưu thế. Cát hoàn toàn vắng mặt (Hình $4 \mathrm{a}, \mathrm{b})$. Trầm tích mịn dần từ dưới lên cho thấy xu thế giảm dần của động lực môi trường [38].

Sự giảm dần kích thước hạt của trầm tích từ thô tới mịn (Hình 4) từ tập $Z_{1}, Z_{2}$ đến $Z_{3}$ phản ánh môi trường lắng đọng trầm tích từ nông tới sâu dần [1].

So với kết quả nghiên cứu của Trần Nghi và nnk, 1991, Doãn Đình Lâm và W. E. Boyd, 2003, Tanabe và CS, 2006, Vũ Văn Lợi, 2017 về lịch sử phát triển của đồng bằng Sông Hồng [1, $9,17,44]$ thì tập $Z_{1}, Z_{2}$ và $Z_{3}$ hình thành trong giai 
đoạn biển tiến sâu vào đất liền và ứng với trầm tích estuary-vũng vịnh. Theo Nicolas, 2009 [39] thì một trong những dấu hiệu của trầm tích esatuary- vũng vịnh là trầm tích mịn dần từ dưới lên. Sự thay đổi về đặc điểm trầm tích trong ba tập này đánh dấu sự tác động của pha biển tiến Flandiran ngày càng mạnh của biển lên vùng ven biển Hải Phòng nói riêng và vùng châu thổ sông Hồng nói chung.

\subsubsection{Chân châu thổ}

Trầm tích chân châu thổ gặp ở độ sâu từ 18,8 đến $15,3 \mathrm{~m}$ được xác định dựa trên sự thay đổi về đặc điểm trầm tích tập $Z_{4}$, ứng với phần giữa của đới DIA-HPZ1. Trầm tích tập $\mathrm{Z}_{4}$ chủ yếu là bột, sét màu xám sẫm chuyển sang màu xám (Hình 4b), xám nhạt. Tập trầm tích này chứa rất ít Diatomeae (Bảng 1), tuy số lượng ít nhưng sự xuất hiện của Coscinodiscus sp. cho thấy sự ảnh hưởng của môi trường biển tới vùng nghiên cứu.

Trầm tích tập $Z_{4}$ thô hơn tập $Z_{3}$ (Hình 4,6 ). Trầm tích thô dần từ dưới lên, chứa vụn thực vật và mảnh vụn sinh vật biển là một trong những dấu hiệu của trầm tích chân châu thổ [17]. Trầm tích màu xám nhạt chuyển dần lên xám nâu, thô dần từ dưới lên với lượng hạt mịn chiếm ưu thế là đặc trưng cho trầm tích chân châu thổ (prodelta) $[9,17,44]$. Tập trầm tích này mang đặc trưng cho kiểu môi trường chân châu thổ (Hình $4 \mathrm{~b}$, Hình 6), đánh dấu quá trình biển bắt đầu thoái.

\subsubsection{Tiền châu thổ}

Tại lỗ khoan HP1, trầm tích tiền châu thổ gặp tại độ sâu từ 15,3 đến $7,8 \mathrm{~m}$, ứng với tập trầm tích số $5\left(Z_{5}\right)$, phần trên của đới Dia-HPZ1, DiaHPZ2 và phần dưới của Dia-HPZ3. Trầm tích màu xám, xám nâu, chứa vụn sinh vật (Hình 4b). Trầm tích tập này có đặc trưng thô dần từ dưới lên (Hình 4a). Sự tăng dần hàm lượng cát từ dưới lên của tập $Z_{5}$ cùng với sự có mặt của vụn sinh vật là một trong những dấu hiệu trầm tích tiền châu thổ $[9,17,44]$. Ngoài ra, một số Diatomeae đặc trưng cho vùng nước lợ ven bờ (độ muối $<30 \%$ ) có mặt trong trầm tích (Hình 6). Đó là Cyclotella striata, Cyc. stylorum, Diploneis smithii và Paralia sulcata trong đới Dia-HPZ2. Các loài Diatomeae nêu trên phản ánh môi trường biển nông ven bờ $[20,21,32,33,42,43]$. Tập $Z_{5}$ nằm phủ trực tiếp lên các trầm tích chân châu thổ (prodelta). Đặc điểm trầm tích cũng như tổ hợp Diatomeae cho thấy trầm tích tập $\mathrm{Z}_{5}$ được hình thành trong môi trường tiền châu thổ (delta front). $\mathrm{Xu}$ thế thay đổi của trầm tích từ tập $\mathrm{Z}_{4}$ sang $Z_{5}$ thể hiện quá trình biển thoái ở khu vực nghiên cứu. Điều này đã được khẳng định trong các công bố trước đây ở vùng nghiên cứu $[9,17,19,44]$.

\subsection{4. Đồng bằng châu thổ}

Tại lỗ khoan HP1, trầm tích đồng bằng châu thổ gặp ở độ sâu từ 7,8 đến $0 \mathrm{~m}$, với sự có mặt của các tập trầm tích $Z_{6}$ và $Z_{7}$ (Hình 4,6 ) ứng với phần trên cùng của đới DIA-HPZ3, đới DIAHPZ4 và đới DIA-HPZ5 (Hình 3). Sự thay đổi độ hạt từ thô sang mịn của tập trầm tích $Z_{6}$ đến $Z_{7}$ đánh dấu sự thay đổi đáng kể của môi trường thành tạo trầm tích. Thành phần giống loài Diatomeae ở tập này (đới DIA-HPZ4 và đới DIA-HPZ5) thay đổi lớn theo chiều nông dần của lỗ khoan (Hình 3).

Tập $\mathrm{Z}_{6}(7,8-3,2 \mathrm{~m})$ có thành phần chủ yếu là cát, bột. So với tập $\mathrm{Z}_{5}$ hàm lượng sét tại tập này giảm rất nhiều (Hình $4 \mathrm{a})$. Trầm tích có màu xám nâu, có chứa vụn vỏ sò (Hình 4b), đôi chỗ có phân lớp sóng xiên. Hệ số mài tròn (Ro) của các hạt cát trong tập $\mathrm{Z}_{6}$ cho thấy đây là vùng chuyển tiếp [38], với $R_{0}=0,5-0,61$ (Hình 5). Số lượng loài cũng như số lượng mảnh vỏ Diatomeae tăng dần từ dưới lên. Nhóm Diatomeae nước lợ trôi nổi và bám đáy chiếm ưu thế, vắng mặt Diatomeae nước ngọt (Bảng 1, Hình 3). U’u thế tuyệt đối của Cyclotella striata và Cyc. Stylorum chiếm tới $80 \%$ trong phức hệ Diatomeae cho thấy trầm tích hình thành trong môi trường biển nông ven bờ $[20,21,23,25,33,42]$. Bên cạnh hai loài này, trong trầm tích tập $Z_{6}$ còn gặp một số loài Diatomeae thuộc nhóm Diatomeae biển trôi nổi như Coscinodiscus lineatus, Coscinodiscus sp. và Diatomeae nước lợ bám đáy với số lượng it nhu Nitzschia cocconeiformis, Diploneis smithii. Sự thay đổi thành phần cũng như số lượng mảnh vỏ Diatomeae trong tập trầm tích $\mathrm{Z}_{6}$ này cho thấy môi trường ở đây có sự xáo trộn lớn nên các loài Diatomeae bám đáy không sống được mà chỉ gặp chủ yếu các loài trôi nổi. Đặc điểm trầm tích cũng như thành phần Diatomeae cho thấy trầm tích của tập này hình thành trong khu vực biển ven bờ. 


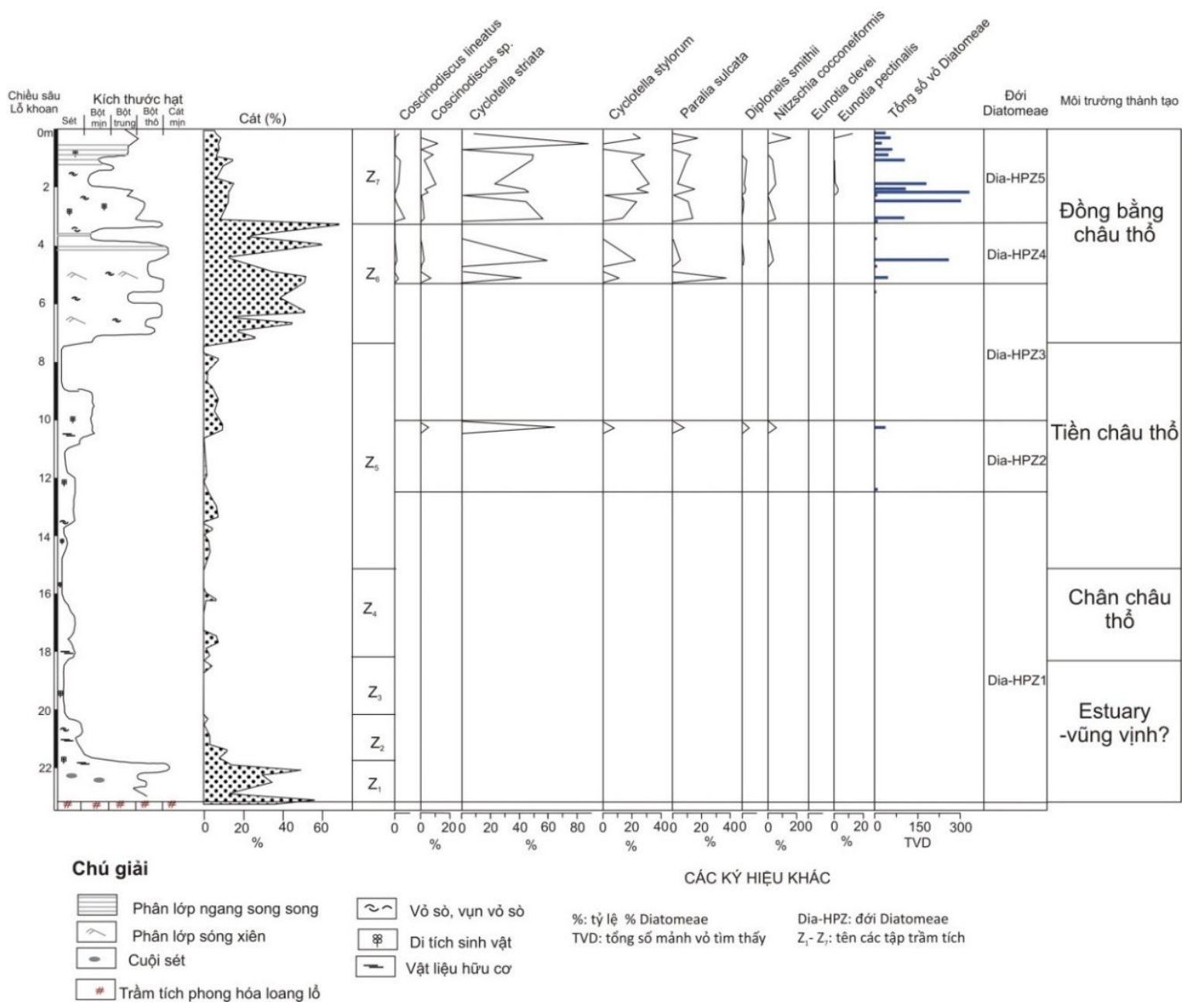

Hình 6. Đặc điểm và môi trường thành tạo trầm tích trong lỗ khoan HP1 (Dương Kinh, Hải Phòng).

Trầm tích tập $\mathrm{Z}_{7}$ có thành phần chủ yếu là bột, sét, đôi chố xen kẹp với lớp cát mỏng, phân lớp sóng xiên (Hình 4b). Đặc biệt trong đới DIAHPZ5 thuộc tập này có sự xuất hiện của Diatomeae nước ngọt cùng với các loài Diatomeae nước mặn và nước lợ, phản ánh sự ảnh hưởng của nước ngọt đến vùng nghiên cứu [23]. Sự có mặt của hai loài chỉ thị cho môi trường bãi triều Nitzschia cocconeiformis, Diploneis smithii [45] số lượng tuy không nhiều nhưng cũng cho thấy vùng nghiên cứu liên quan đến hoạt động của triều. Như vậy trầm tích chứa Diatomeae với sự có mặt chủ đạo của các loài nước lợ và một số dạng nước ngọt phản ánh ảnh hưởng của đới triều [46] nên mới có mặt đầy đủ thành phần Diatomeae nước lợ, nước mặn và nước ngọt. Từ các đặc điểm nêu trên cho thấy tập $\mathrm{Z}_{7}$ được hình thành trong môi trường cửa sông ven biển với ảnh hưởng lớn của sông, đánh dấu sự lùi ra của biển trong Holocen. Tập trầm tích $Z_{6}$ và $Z_{7}$ hình thành trong môi trường châu thổ (delta plain) chịu sự ảnh hưởng của triều là chủ yếu $[4,9,16,39]$.

\section{Kết luận}

- Năm đới sinh thái Diatomeae (ecodiatom zone) đã được xác lập tại vùng nghiên cứu dựa trên sự có mặt cũng như đặc điểm phân bố trong trầm tích của 52 loài thuộc 21 giống Diatomeae 
đã được xác định, trong đó 24 loài thuộc phụ lớp Diatomeae lông chim (Pennatophyceae) và 28 loài thuộc phụ lớp Diatomeae trung tâm (Centrophyceae). Các đới sinh thái Diatomeae lần lượt như sau: DIA-HPZ1, DIA-HPZ2, DIAHPZ3, DIA-HPZ4 và DIA-HPZ5. Đới DIAHPZ1 và DIA-HPZ3 đặc trưng bởi hầu như vắng mặt Diatomeae trong trầm tích. Đới DIA-HPZ2 đặc trưng bởi sự hiếm gặp Diatomeae. DIAHPZ4 đặc trưng bởi sự có mặt của ba nhóm Diatomeae biển trôi nổi, nước lợ trôi nổi và bám đáy, trong đó phong phú nhất là Diatomeae nước lợ trôi nổi. Đới DIA-HPZ5 đặc trưng bởi sự có mặt của Diatomeae nước ngọt bên cạnh ba nhóm Diatomeae nói trên.

- Bốn kiểu môi trường thành tạo trầm tích đã được xác định trên cơ sở đặc điểm trầm tích và đặc điểm phân bố Diatomeae: môi trường estuary-vũng vịnh, ứng với tập trầm tích $Z_{1}, Z_{2}$ và $Z_{3}$, hình thành trong giai đoạn biển tiến Flandrian; môi trường chân châu thổ ứng với tập trầm tích $Z_{4}$; môi trường tiền châu thổ ứng với tập $Z_{5}$; môi trường đồng bằng châu thổ ứng với tập trầm tích $Z_{6}$ và $Z_{7}$. Sự thay đổi thành phần của các tập trầm tích $Z_{4}, Z_{5}, Z_{6}$ và $Z_{7}$ cho thấy vùng đồng bằng châu thố ven biển Hải Phòng là vùng bị ảnh hưởng của triều.

\section{Lời cảm ơn}

Bài báo nhận được sự hỗ trợ kinh phí của đề tài mã số: 105.03-2015.35 do Quỹ Nafosted tài trợ. Bên cạnh đó, bài báo được thực hiện việc gia công và phân tích mẫu tại phòng thí nghiệm Khoa Địa chất, Trường Đại học Khoa học Tự nhiên và phòng Trầm tích, Viện Địa chất, Viện Hàn Lâm KH\&CNVN. Nhân dịp này nhóm tác giả xin gửi lời cảm ơn chân thành tới các cơ quan nói trên.

\section{Tài liệu tham khảo}

[1] Tran Nghi, Ngo Quang Toan, Do Thi Van Thanh, Nguyen Dinh Minh, Nguyen Van Vuong, Quaternary sedimentation of the principal deltas of Vietnam, Journal of Southeast Asian Earth
Sciences 6 (1991) 103-110. https://doi.org/10. 1016/0743-9547(91)90101-3

[2] Thi Kim Oanh Ta, Van Lap Nguyen, Masaaki Tateishi, Iwao Kobayashi, Yoshiki Saito, Toshio Nakamura, Sediment facies and Late Holocene progradation of the Mekong delta in Bentre province, southern Vietnam: an example of evolution from a tide-dominated to a tide- and wave-dominated delta, Sedimentary Geology 152 (2002) 313-325. https://doi.org/10.1016/S00370738(02)00098-2

[3] Kazuaki Hori, Susumu Tanabe, Yoshiki Saito, Shigeko Haruyama, Viet Nguyen, Akihisa Kitamura, Delta initiation and Holocene sea-level change: example from the Song Hong (Red River) delta, Vietnam, Sedimentary Geology 164 (2004) 237249. https://doi.org/10.1016/j.sedgeo.2003.10.008

[4] Nguyen Thi Hong Lieu, PhD thesis: Holocene evolution of the central Red River delta, northern Vietnam lithological and mineralogical investigations, Dissertation in fulfillment of the academic grade doctor rerum naturalium, Germany, 2006.

[5] Dinh Van Thuan, Nguyen Dich Dy, Nguyen Bao Khanh, The characteristics of the distribution of mangrove vegetation in Holocene sediments in coastal delta of Vietnam,Vietnam journal of Earth sciences 18(2) (1996) 96-98 (in Vienamese).

[6] M.R. McQuoid, K. Nordberg, The diatom Paralia sulcata as an environmental indicator species in coastal sediments, Estuarine, Coastal and Shelf Science 56 (2003) 339-354. https://doi.org/10. 1016/S0272-7714(02)00187-7

[7] Dinh Van Thuan, Nguyen Dich Dy, Mangrove development in relation to transgression and regression times in Quaternary at the Cuu Long Delta,Vietnam journal of Earth sciences 22(2)(2004) 120-126 (in Vienamese).

[8] Nguyen Thuy Duong, Disertation: Palaeoecology of the Red River delta in the Holocene: A palynotological approach, Germany, 2006.

[9] Doan Dinh Lam, W.E. Boyd, Holocene coastal stratigraphy and the Sedimentary development of the Hai Phong area of the Bac Bo Plain (Red River Delta), Vietnam, Australian Geographer 34(2) (2003) 177-194. https://doi.org/10.1080/0004918 0301737

[10] Y. Zong, W.W.-S. Yim, F. Yu b, G. Huang, Late Quaternary environmental change in the Pearl River mouth region, China, Quaternary International 206 (2009) 35-45. https://doi.org/10. 1016/j.quaint.2008.10.012. 
[11] Nguyen Thi Thu Cuc, Dao Thi Mien, Vu Van Ha, Diatomeae and paleoecological significant in the Holocene and surface sediment at the River mouth of the Tien river,Jounal of Science and Technology, 48 (2A) (2010) 856-866 (in Vienamese).

[12] Z. Xue, J.P. Liu, D. DeMaster, Nguyen Van Lap, Ta Thi Kim Oanh, Late Holocene Evolution of the Mekong Subaqueous Delta, Southern Vietnam, Marine Geology 269 (2010) 46-60. https://doi.org/ 10.1016/j.margeo.2009.12.005

[13] Nguyen Van Lap, Ta Thi Kim Oanh, Y. Saito, Early Holocene initiation of the Mekong River delta, Vietnam, and the response to Holocene sealevel changes detected from DT1 core analyses, Sedimentary Geology 230 (2010) 146-155.https:// doi.org/10.1016/j.sedgeo.2010.07.006

[14] Nguyen Thi Thu Cuc, Doan Dinh Lam, Diatom Responses to Holocene Environmental Changes in the Tiền Delta- Mekong River System, VNU Journal of Earth and Environmental Sciences 29 (3)(2013) 14-25. https://js.vnu.edu.vn/EES/article/ view/1101

[15] A.A. Kakroodi, S.A.G. Leroy, S.B. Kroonenberg, H.A.K. Lahijani, H. Alimohammadian, I. Boomer, A. Goorabi, Late Pleistocene and Holocene sealevel change and coastal paleoenvironment evolution along the Iranian Caspian shore, Marine Geology 361 (2015) 111-125. https://doi.org/10. 1016/j.margeo.2014.12.007

[16] Tran Duc Thanh, Holocene stratigraphy and the structure of intertidal flats in the Hai Phong coastal area, Vietnam Journal of Earth Sciences 27(3) (1999) 197-206 (in Vietnamese).

[17] S. Tanabe, Y. Saito, Vu Quang Lan, J.J. Hanebuth, A. Kitamura, Holocene evolution of Song Hong (Red River) delta system, northern Vietnam, Sedimentary Geology 187 (2006) 29-61. https:// doi.org/10.1016/j.sedgeo.2005.12.004

[18] Doan Dinh Lam, Delta lobes of the Red River Delta, Vietnam Journal of Geology A/308 (2008) 59-67 (in Vietnamese).

[19] Ayako Funabiki, Shigeko Haruyama, Nguyen Van Quy, Pham Van Hai, Dinh Hung Thai, Holocene delta plain development in the Song Hong (Red river) delta Vietnam, Journal of Asian Earth Sciences 30 (2007) 518-529. https://doi.org/10. 1016/j.jseaes.2006.11.013

[20] Yongqiang Zong, Andrew C. Kemp, Jeremy M. Lloyd, Guangqing Huang, Diatoms from the Pearl River estuary, China and their suitability as water salinity indicators for coastal environments, Marine micropaleontology 75 (2010) 38-49. https: //doi.org/10.1016/j.marmicro.2010.02.004
[21] Yeu Huang, Hui Jiang, Michael Sarnthein, Karen Luise Knudsen, Dongling Li, Diatom response to changes in paleoenvironments of the northern South China Sea during the last 15000 years, Marine Micropaleontology 72(2009) 99-109. https://doi.org/10.1016/j.marmicro.2009.04.003.

[22] Caroline Marie B. Jaraula, Fernando P. Siringan, Ralf Klingel, Hiroshi Sato, Yusuke Yokoyama, Records and causes of Holocene salinity shifts in Laguna de Bay, Philippines, Quaternary International 349 (2014) 207-220. https://doi.org/ 10.1016/j.quaint.2014.08.048

[23] Dongyan Liu, Lixue Liu, Baoping Di, Yujue Wang, Yanna Wang, Paleoenvironmental analyses of surface sediments from the Bohai Sea, China, using diatoms and silicoflagellates, Marine Micropaleontology 114 (2015) 46-54. https://doi. org/10.1016/j.marmicro.2014.11.002

[24] Ji-Hoon Park, Sangheon Yi, Hyundok Oh, Bin Xue, Holocene shoreline displacement on the Gungnam Plain, Buyeo, near the central west coast of South Korea inferred from diatom assemblages, Quaternary International 384 (2015) 129-138. https://doi.org/10.1016/j.quaint.2015.04.046

[25] Yoshiki Sato, Hiromi Matsuoka, Makoto Okamura, Kaoru Kashima, Late Holocene environmental changes of coastal lagoon inferred from a fossil diatom analysis of sediment core from Lake Hamana, central Japan, Quaternary International 397 (2016) 317-329. https://doi.org/ 10.1016/j.quaint.2015.06.006

[26] Ikuko Tnaka, Masayuki Hyodo, Yusuke Ueno, Ikuko Kitaba, Hiroshi Sato, High-resolution diatom record of paleoceanographic variations across the Early-Middle Pleistocene boundary in the Chiba Section, central Japan, Quatery international 455 (2017) 141-148. https://doi.org/ 10.1016/j.quaint.2017.08.017

[27] Dao Thi Mien, Le Van Vo, Nguyen Ngoc, Nguyen Thi Thu Cuc, Holocene microfossils (Diatoms and Foraminifers) and theirs sedimentary conditions in the Thanh Hoa plain,Vietnam Journal of Earth Sciences23(1) (2001) 33-41 (in Vietnamese). https://doi.org/10.15625/0866-7187/23/1/11308

[28] Dao Thi Mien, Nguyen Ngoc, Nguyen Thi Thu Cuc, Significance of diatom complexes in the determination of sediment origin at the end of Midde Holocene - late Holocene some coastal delta of Vietnam, Journal of Geology 295 (2006) 1-14 (in Vietnamese).

[29] Juliane Fenner, Late Cretaceous to Oligocene planktic diatoms. InHans M. Bolli, John B. Saunders, Katharina Perch-Nielsen, Plankton 
Stratigraphy, Cambridge University Press,1989, 713-762.

[30] Жузе, Атлас микроорганизмов в донных осадках (диатомеи, радиоларии, силикофлигелляты, кокколиты), М. "Наука", 1977г.

[31] F.E. Round, R.M. Crawford, D.G. Mann, The Diatoms: biology and morphology of genera, Cambridge University press, 1990.

[32] Truong Ngoc An, Classification of marine phytoplankton in Vietnam, Science and Technology Publishing, Hanoi, 1993.

[33] G.R. Hasle, E.E. Syvertsen, Marine diatoms 34, In Carmelo R. Tomas et al., Identifying Marine phytoplankton, Acadamic press, 1996.

[34] S.R. Stidolph, F.A.S. Sterrenburg, K.E.L. Smith, A. Kraberg, Stuart R, Stidolph Diatom Atlas, U.S. Geological Survey Open-File Report 20122012 1163, 199 , available at In http://pubs.usgs.gov/of/ 2012/1163/.

[35] Nguyen Thi Thu Cuc, PhD thesis:Stratigraphy and sedimentary environment of Holocene along Tien river coast, VNU University of Science,2015 (in Vietnamese).

[36] J.M. Palmer, W.H. Abbott, Diatom as indicators of sea-level change. In book: Sea-level research a manual for the collection and evaluation of data, Spinger, p. 457-487. 1986.

[37] S. Juggins,C2 Version 1.5 User guide, Software for ecological and palaeoecological data analysis and visualisation, Newcastle University, Newcastle upon Tyne, UK, 2007.

[38] Tran Nghi, Sedimentology,Vietnam National University Press, Hanoi, 1999 (in Vietnamese).

[39] Gary Nichols, Sedimentology and stratigraphy, Second edition, Blackwell Publishing, 2009.
[40] Ta Hoa Phuong, Paleontology, Vietnam National University Press, Hanoi, 2003 (in Vietnamese).

[41] Nguyen Thuy Duong, 2016, Paleoecology, in Tong Duy Thanh, Mai Trong Nhuan, Tran Nghi (Eds), Encyclopedia of Geology, Vietnam National University Press, Hanoi, pp76-77 (in Vietnamese).

[42] W.S. Wyss, Yima, J. Li, Diatom preservation in an inner continental shelf borehole from the South China Sea, J. of Asian Earth Sciences 18 (2000) 471-488. https://doi.org/10.1016/S1367-9120(99) 00079-6

[43] Pauline SnoeijS, Kaarina Weckström, Diatoms and environmental change in large brackish-water ecosystems (in book The Diatoms Applications for the Environmental and Earth Sciences (Second Edition), Edited by John P. Smol Eugene F. Stoermer, Published in the United States of America by Cambridge University Press, New York, 2010.

[44] Vu Van Loi, PhD thesis: Research on characteristic and distribution of the Holocene sediments in the coastal areas of Haiphong city for infrastructure development, 2017 (in Vietnamese).

[45] M. Gomes, M.S. Humphries, K.L. Kirsten, A.N. Green, J.M. Finch, A.M. Lecea, Diatom-inferred hydrological changes and Holocene geomorphic transitioning of Africa's largest estuarine system, Lake St Lucia, Estuarine, Coastal and Shelf Science 192 (2017) 170-180. https://doi.org/ 10.1016/j.ecss.2017.03.030

[46] Haixian Xiong, Yongquiang Zong, Peng Quian, Guangqing Huang, Shuqing Fu, Holocene sea level histofy of the northern coast of South China Sea, Quaternary Science Reviews 194 (2018) 1226. https://doi.org/10.1016/j.quascirev.2018.06.022. 